\title{
Market and Welfare Effects of Food Security Policies on Smallholder Rice Farmers and Consumers in Sierra Leone
}

\author{
Mohamed Ajuba Sheriff ${ }^{1,2}$, Kepifri A. Lakoh ${ }^{1}$, Bob K. Conteh ${ }^{1} \&$ Tharcisse Nkunzimana ${ }^{3}$ \\ ${ }^{1}$ Department of Agricultural Economics, Njala University, Sierra Leone \\ ${ }^{2}$ Ministry of Agriculture, Forestry and Food Security (MAFFS), Sierra Leone \\ ${ }^{3}$ European Commission, DG International Cooperation and Development, Unit C.1: Rural Development, \\ Agriculture, Food \& Nutrition Security, Brussels, Belgium \\ Correspondence: Kepifri A. Lakoh, Department of Agricultural Economics, Njala University, Sierra Leone. \\ E-mail: kepifri@huskers.unl.edu
}

Received: January 12, 2020

Accepted: April 2, $2020 \quad$ Online Published: May 15, 2020

doi:10.5539/jas.v12n6p76

URL: https://doi.org/10.5539/jas.v12n6p76

\begin{abstract}
This research examines the market and welfare effects of three food security policy options in Sierra Leone in response to the high rate of rice importation and rising rice prices over the last decade. These policies aimed at curbing the rate of rice importation, promoting local rice production, and enhancing welfare of smallholder rice farmers in rural communities. The policies investigated included: 1) reinstating tariffs on rice imports, 2) promoting value-chain strengthening interventions that increase production of locally produced rice and 3) instituting a quota (or some quantity restriction) on rice imports. A log-linear comparative static displacement model was used to carry out the analysis. For the first policy, $20 \%, 30 \%$ and $40 \%$ shocks were introduced in the equilibrium system to represent decreases in the quantity of rice imported as a result of reinstating tariffs on imported rice. Results revealed that welfare of consumers and or smallholder farmers of locally produced rice was enhanced by $9.4 \%$ at a $10 \%$ tariff increase and $17.8 \%$ at a $20 \%$ tariff increase. Consumers of imported rice had their welfare enhanced by $3.5 \%$ at a $10 \%$ tariff increase while welfare was dis-enhanced by $5.4 \%$ at a $20 \%$ tariff increase. With a $10 \%$ increase in the supply of locally produced rice, there was a corresponding welfare enhancement on smallholder rice farmers and consumers by $14.43 \%$ and by $27 \%$ for a $20 \%$ increase in supply. Marginal increases were recorded for consumers of imported rice. The results show that the optimal policy in the current post-Ebola national recovery environment is one that increases local rice production through cultivation intensification and rice value chain efficiency.
\end{abstract}

Keywords: comparative static, consumer surplus, food security policies, market effects, partial equilibrium displacement model, producer surplus, welfare effects

\section{Introduction}

\subsection{Introduction}

Food insecurity continues to be a major problem in Sierra Leone. Despite reported increases in the production of the country's main staple crop (rice), national demand for locally produced rice remains very low (particularly in the populated urban areas of Sierra Leone), accounting for the negligible effects of the increased level of rice production on food security (Spencer et al., 2009). At the rural household level, local rice consumption follows a seasonal pattern (high during the rice harvesting season and low during the rice planting season). This premise may suggest that the problem of low demand for locally produced rice in urban areas is driven mainly by consumer preferences and the problems at the rural household level are as a result of seasonal shortages. However, some recent evidences have shown that the drivers of the problems affecting the rice sector are more complex.

The average rice farmer in Sierra Leone cannot compete with retailers of imported rice in the domestic market. This is mainly because of the high cost of production (relative to yields) incurred by smallholder rice farmers, limiting their ability to set prices at or below the market price for imported rice (World Bank, 2014). This has also led to a dampened effect on demand for locally produced rice, disincentivizing smallholder farmers from increasing production levels to meet both their profit-seeking objectives and their household consumption needs. 
Sierra Leone is a net rice consuming country, particularly with regards to locally produced rice. Historic data (2000 to 2015) from the Ministry of Agriculture and Food Security (MAFS) on volumes of rice imports, local rice production and local rice consumption shows that total demand from 2002 to 2008 matched the total volumes imported and produced locally. However, between 2008 and 2015, the sum of total rice produced locally, and total volumes imported surpassed total rice consumption. In 2013, total rice production was higher than total consumption and remained in that average through 2015. This may further suggest that some amounts of the total rice supply (imported and locally produced) is not consumed locally. That is, the total volume of rice supplied into the local market outweighed local consumer demand. However, in 2015, a different trend was observed. Total rice import $(25,165 \mathrm{MT})$ plus total rice production $(597,866.96 \mathrm{MT})$ was less than rice consumption $(735,866.66 \mathrm{MT})$. This may suggest that some amount of local rice demand $(113,485.66 \mathrm{MT})$ was unaccounted for. These anomalies have been of concern to researchers and policy makers in the country as they seek answers to problems facing the sector. Specifically, the following patterns seem slightly counterintuitive: i) increased production of locally produced rice; ii) an irresponsive local rice demand to the increased production level and iii) increased consumer demand for imported rice.

Furthermore, between 2010 and 2017, Sierra Leone spent about 800 million USD on rice importation, averaging about 100 million USD annually (World Data Atlas, 2018). Servicing these funds by the Sierra Leone Central Bank created severe shocks to the country's foreign exchange reserves. Some economists argue that these shocks have also affected some key macroeconomic indicators like foreign exchange rates, inflation rates, Gross Domestic Product (GDP) etc. As the government seeks answers to these challenges and anomalies, different policy options are being explored. It is critical to understand the ramifications of possible policy options before they are considered. This research provides some empirical evidence that can guide policy makers as they grapple with this problem.

\subsection{Objectives}

In trying to provide solutions to some of these problems affecting the rice sector in the country, it is important that policy makers understand all the dynamics associated with the rice sector in the country. This research specifically seeks to analyse the market and welfare effects of three talked-about polices/instruments being considered by policy makers. The results obtained by this research presents potential gains or losses to producers and consumers of rice in Sierra Leone should either policy option be enacted. We hypothesize that all three policies considered positively enhances welfare of smallholder farmers. The three policy options include:

i) The effect of reinstating tariffs on rice imports on markets and welfare of rice consumers and producers.

ii) The effect of instituting a quota (or some quantity restriction) on rice imports on markets and welfare of rice consumers and producers.

iii) The effect of increase local rice production (supply) through subsidies for smallholder farmers (A value-chain, multi-intervention approach).

At the global level, rice production has risen steadily from about 131 million tonnes of paddy rice in 1960 to over 678 million tonnes in 2009. The top four producers have been China, India, Indonesia, and Pakistan. Hybrid rice varieties helped to significantly increase global rice production by about 10 million tonnes annually. Within the Mano River Union (MRU) countries, Sierra Leone is the fastest growing rice producing country after the civil war compared to Liberia and Guinea. Cereal production doubled between 2000 and 2008 in Liberia and quadrupled in Sierra Leone over the same period (FAOSTAT, 2015). However, despite this increase in cereal production, both Liberia and Sierra Leone have remained food-deficient countries, respectively importing between a third and half of their annual total cereal requirements (FAO/WFP, 2015).

Regarding consumption, annual per capita consumption in Sierra Leone averages about $131 \mathrm{~kg}$ (FAO, 2014). Despite being a net rice consuming country, Sierra Leone also exports significant quantities of rice to Guinea. According to Guinea's systeme d'information sur les produits Agricoles en Guineee (SIPAG, 2012; FEWSNET, 2010), some 360 tons of milled local parboiled rice entered Guinea from Sierra Leone every month during the final quarter of 2009. This cross-border effect also affects prices, consumption, and welfare generally.

Research on the effects of food security policies on smallholder farmers in Sierra Leone is limited. The few available studies (Conteh et al., 2012; Spencer et al., 2009) have focused on providing accounts of the drivers limiting production and survey accounts of the problems within the sector. Literature on agricultural policy research in Sierra Leone (FAO, 2013; Spencer et al., 1997) were focused on providing macro-level analysis of various policies on the rice sector. There are no published accounts of national food policy effects on smallholder 
farmers at the micro level. This research provides a framework that can be used for the analysis of multiple policies in the future at the micro level.

\section{Methods}

In this section, we describe the key methods that were used to carry out this research. Based on the objectives of the research, Equilibrium-Displacement Models (EDM) were used for the analysis. Using identical general equilibrium frameworks like those used by Muth (1964), Sumner et al. (1985) with modifications by Perrin (1997), and Salhofer et al. (1999), a partial equilibrium displacement model (P-EDM) was used to carryout this analysis. Log-linear comparative statics in a multi-market environment was used to determine market effects while consumer surplus and producer surplus measures were used as estimates of welfare. The analysis shows the effect of introducing shocks to a partial equilibrium system and how this system changes or responds to these shocks.

The choice of P-EDM for this policy analysis is predicated on a long and continuing literature that compares General Equilibrium frameworks to P-EDM. There are indeed compelling cases for both categories of models. For instance, Hertel $(1992,2002)$ and others discussed the pros and cons of these two models showing ideal circumstances for their use. However, for this research, we heed to Gohin et al.'s (2006) confirmation that the choice of the model solely depends on the choice and estimation of elasticities and on the underlying assumptions made. In addition to this theoretic basis, our choice was also based on simplicity of estimation (given the inherent data challenges prevailing in Sierra Leone) and an attempt to focus solely on the rice sector.

\subsection{The Model}

For this analysis, we assume two up-stream horizontally linked markets (imported rice and locally produced rice) and four downstream input markets that are also horizontally linked (Land, Labour, Fertilizer and Other). The inputs are used only in the production of locally produced rice and linked by a production function (by duality, represented as a cost function) $\mathrm{C}\left(\mathrm{Q}_{\mathrm{L}}, \mathrm{W}_{\mathrm{L}}, \mathrm{W}_{\mathrm{Lb}}, \mathrm{W}_{\mathrm{O}}, \mathrm{W}_{\mathrm{f}}\right)$. That is, a cost function was used to characterize the rice production technology. $\mathrm{Q}$ representing production levels of locally produced rice and $\mathrm{W}(\mathrm{L}, \mathrm{Lb}, \mathrm{f} \& \mathrm{O})$ represents input costs for Land, Labour, Fertilizer and Others.

Equilibrium graphs are presented in Figure 1 below:

\section{Local Rice}

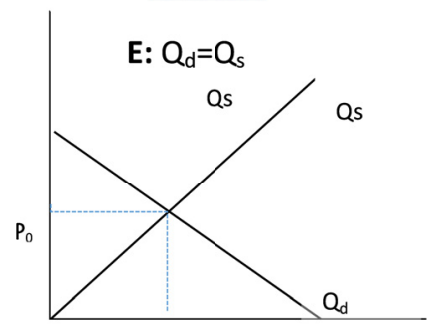

$\mathrm{Q}_{0}$
Imported Rice

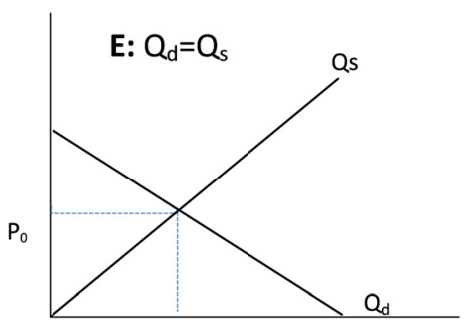

$\mathrm{a}_{0}$

$$
\mathrm{C}\left(\mathrm{Q}^{\mathrm{L}}, \mathrm{W}^{\mathrm{L}}, \mathrm{W}^{\mathrm{Lb}}, \mathrm{W}^{\mathrm{O}}, \mathrm{W}^{\mathrm{f}}\right)
$$

Land

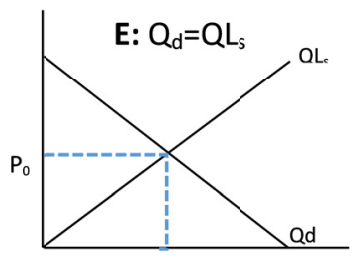

$\mathrm{Q}_{0}$
Labour

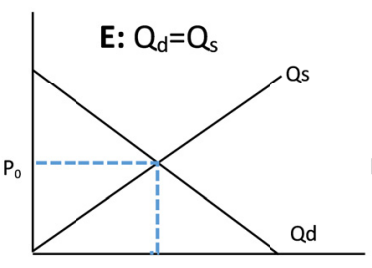

$\mathrm{Q}_{0}$

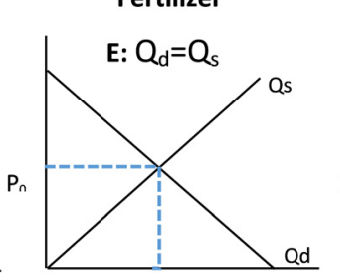

$\mathrm{Q}_{0}$
Others

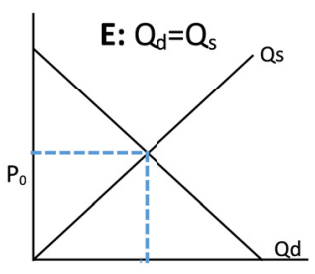

Q

Figure 1. Multi-market equilibrium graphs

Using log-linear comparative static, 12 demand and supply equations were derived. These equations represent 12 endogenous and 12 exogenous variables. The Objective is to use the exogenous variables to solve for the 
endogenous parameters. The exogenous variables are mainly elasticities and shares while the endogenous parameters are the market effects (changes in quantity demanded, supplied and prices).

\subsection{System of Equations}

2.2.1 Demand Equations

$$
\begin{aligned}
& Q_{d}^{L}=f\left(p^{L}, p^{I}\right) \\
& Q_{d}^{I}=f\left(p^{I}, p^{L}\right)
\end{aligned}
$$

Demand for locally produced rice depends on the prices of both local and imported rice

2.2.2 Supply Equations

$$
\begin{gathered}
\mathrm{C}_{\mathrm{QL}}\left(\mathrm{Q}_{\mathrm{L}} \mathrm{Q}_{\mathrm{QL}}, \mathrm{w}^{\mathrm{L}}, \mathrm{w}^{\mathrm{f}}, \mathrm{w}^{\mathrm{Lb}}, \mathrm{w}^{\mathrm{O}}\right)=\mathrm{P}^{\mathrm{QL}} \\
\mathrm{C}_{\mathrm{QI}}\left(\mathrm{Q}_{\mathrm{L}} \mathrm{Q}_{\mathrm{QL}}, \mathrm{w}^{\mathrm{L}}, \mathrm{w}^{\mathrm{f}}, \mathrm{w}^{\mathrm{Lb}}, \mathrm{w}^{\mathrm{O}}\right) \mathrm{t}+\mathrm{a}=\mathrm{P}^{\mathrm{QI}}
\end{gathered}
$$

2.2.3 Output Constant

2.2.4 Input Supply

$$
\begin{aligned}
\mathrm{C}_{\mathrm{wL}} & =\mathrm{L} \\
\mathrm{C}_{\mathrm{wLb}} & =\mathrm{Lb} \\
\mathrm{C}_{\mathrm{wF}} & =\mathrm{F} \\
\mathrm{C}_{\mathrm{wO}} & =\mathrm{F}
\end{aligned}
$$

$$
\begin{aligned}
& \mathrm{L}=\mathrm{g}\left(\mathrm{W}^{\mathrm{L}}, \mathrm{W}^{\mathrm{f}}, \mathrm{W}^{\mathrm{Lb}}, \mathrm{W}^{\mathrm{o}}\right) \\
& \mathrm{F}=\mathrm{g}\left(\mathrm{W}^{\mathrm{L}}, \mathrm{W}^{\mathrm{f}}, \mathrm{W}^{\mathrm{Lb}}, \mathrm{W}^{\mathrm{o}}\right) \\
& \mathrm{Lb}=\mathrm{e}\left(\mathrm{W}^{\mathrm{L}}, \mathrm{W}^{\mathrm{f}}, \mathrm{W}^{\mathrm{Lb}}, \mathrm{W}^{\mathrm{o}}\right) \\
& \mathrm{O}=\mathrm{f}\left(\mathrm{W}^{\mathrm{L}}, \mathrm{W}^{\mathrm{f}}, \mathrm{W}^{\mathrm{Lb}}, \mathrm{W}^{\mathrm{o}}\right)
\end{aligned}
$$

\subsection{Log-Linear Comparative Static Equations}

Using log-linear comparative statics, the above equations are transformed into a system of 12 equations expressed as elasticities, shares and measures of market and welfare changes.

These are presented below:

The following is a key describing the variables presented in the equations below:

$\mathrm{Q}^{\mathrm{L}}=$ Equilibrium quantity of Local Rice;

$\mathrm{Q}^{\mathrm{I}}=$ Equilibrium quantity of Imported Rice;

$\mathrm{P}^{\mathrm{QL}}=$ Equilibrium Price of Local Rice;

$\mathrm{P}^{\mathrm{QI}}=$ Equilibrium Price of Imported Rice;

$\mathrm{W}^{\mathrm{L}}=$ Land prices;

$\mathrm{W}^{\mathrm{Lb}}=$ Prices of labour;

$\mathrm{W}^{\mathrm{f}}=$ Prices of fertilizer;

$\mathrm{W}^{\mathrm{O}}=$ Prices of other inputs;

$\mathrm{L}=$ Total Land used by local rice producers;

$\mathrm{O}=$ Other inputs used by the local rice producing industry;

$\mathrm{Lb}=$ Labour;

$\mathrm{F}=$ Fertilizer.

2.3.1 Demand Equations ( $\mathrm{H}=$ Elasticity)

$$
\begin{gathered}
\mathrm{dIn}^{\mathrm{L}}=\mathrm{H}_{\mathrm{QL} / \mathrm{p}}^{\mathrm{QL}} \mathrm{dIn} \mathrm{P}^{\mathrm{QL}}+\mathrm{H}_{\mathrm{QL} / \mathrm{p}}^{\mathrm{QI}} \mathrm{dInP}^{\mathrm{QI}} \\
\mathrm{dIn} \mathrm{Q}^{\mathrm{I}}=\mathrm{H}_{\mathrm{QL} / \mathrm{p}}^{\mathrm{QI}} \mathrm{dIn} \mathrm{P}^{\mathrm{QI}}+\mathrm{H}_{\mathrm{Q} / \mathrm{p}}^{\mathrm{QL}} \mathrm{dInP}^{\mathrm{QL}}
\end{gathered}
$$

Equations one and two represent demands for local and imported rice respectively. 


\subsubsection{Supply Equations $\left(\sum=\right.$ Elasticity $)$}

$$
\begin{aligned}
& \left(\Sigma_{\mathrm{QL}} \mathrm{S}_{/ \mathrm{P}}\right)^{-1} \mathrm{dInQ}^{\mathrm{Ls}}+\left(\Sigma_{\mathrm{QI}^{\mathrm{S}} / \mathrm{P}^{\mathrm{QI}}}\right)^{-1} \mathrm{dInQ}^{\mathrm{Is}}+\left(\Sigma_{\mathrm{W}^{\mathrm{L}} / \mathrm{P}}\right)^{-1} \mathrm{dInW}^{\mathrm{Ls}}+\left(\Sigma_{\mathrm{W}^{\mathrm{O}} / \mathrm{P} \mathrm{QL}}\right)^{-1} \mathrm{dInW}^{\mathrm{O}} \\
& +\left(\Sigma_{\mathrm{W}^{\mathrm{f}} / \mathrm{P}}\right)^{-1} \mathrm{dInW}^{\mathrm{f}}+\left(\Sigma_{\mathrm{W}^{\mathrm{Lb} / \mathrm{P}^{\mathrm{QL}}}}\right)^{-1} \mathrm{dIn}^{\mathrm{Lb}}=\mathrm{dInP}^{\mathrm{QL}} \\
& \left(\Sigma_{\mathrm{QL}^{\mathrm{S}} / \mathrm{P}^{\mathrm{QI}}}\right)^{-1} \mathrm{dInQ}^{\mathrm{Ls}}+\left(\Sigma_{\mathrm{QI}^{\mathrm{S}} / \mathrm{P}^{\mathrm{QI}}}\right)^{-1} \mathrm{dInQ}^{\mathrm{Is}}+\left(\Sigma_{\mathrm{W}^{\mathrm{L}} / \mathrm{P}^{\mathrm{QI}}}\right)^{-1} \mathrm{dInW}^{\mathrm{L}}+\left(\Sigma_{\mathrm{W}_{\mathrm{O}} / \mathrm{P}^{\mathrm{QI}}}\right)^{-1} \mathrm{dInW}^{\mathrm{O}} \\
& +\left(\Sigma_{\mathrm{W}_{\mathrm{f}}^{\mathrm{f}} \mathrm{P}^{\mathrm{QI}}}\right)^{-1} \mathrm{dInW}^{\mathrm{f}}+\left(\Sigma_{\mathrm{W}^{\mathrm{Lb} / \mathrm{P}^{\mathrm{QI}}}}\right)^{-1} \mathrm{dInW}^{\mathrm{Lb}}+\mathrm{t}+\mathrm{a}=\mathrm{dInP}^{\mathrm{Qi}}
\end{aligned}
$$

On the supply side, two cost functions will be used. One for local rice production, $\mathrm{C}_{\mathrm{QL}}\left(\mathrm{Q}_{\mathrm{L}}, \mathrm{w}^{\mathrm{L}}, \mathrm{w}^{\mathrm{f}}, \mathrm{w}^{\mathrm{Lb}}, \mathrm{w}^{\mathrm{O}}\right)$ and another for imported rice production $\mathrm{C}_{\mathrm{QI}}\left(\mathrm{Q}_{\mathrm{L}}, \mathrm{w}^{\mathrm{L}}, \mathrm{w}^{\mathrm{f}}, \mathrm{w}^{\mathrm{Lb}}, \mathrm{w}^{\mathrm{O}}\right)$.

\subsubsection{Output Constant Derived Demand}

$$
\begin{aligned}
& Z_{\mathrm{L} / \mathrm{QL}} \mathrm{dIn} \mathrm{Q}^{\mathrm{Ls}}+\mathrm{Z}_{\mathrm{L} / \mathrm{W}^{\mathrm{L}}} \mathrm{dInW} \mathrm{W}^{\mathrm{L}}+\mathrm{Z}_{\mathrm{L} / \mathrm{W}^{\mathrm{O}}} \mathrm{dInW}^{\mathrm{O}}+\mathrm{Z}_{\mathrm{L} / \mathrm{W}^{\mathrm{Lb}}} \mathrm{dInW}^{\mathrm{Lb}}+\mathrm{Z}_{\mathrm{L} / \mathrm{W}^{\mathrm{f}}} \mathrm{dInW}^{\mathrm{f}} \\
& \mathrm{Z}_{\mathrm{O} / \mathrm{QL}} \mathrm{dInQ} \mathrm{Q}^{\mathrm{Ls}}+\mathrm{Z}_{\mathrm{O} / \mathrm{W}^{\mathrm{L}}} \mathrm{dInW}^{\mathrm{L}}+\mathrm{Z}_{\mathrm{O} / \mathrm{W}^{\mathrm{O}}} \mathrm{dInW}^{\mathrm{O}}+\mathrm{Z}_{\mathrm{O} / \mathrm{W}^{\mathrm{Lb}}} \mathrm{dInW}^{\mathrm{L}}+\mathrm{Z}_{\mathrm{O} / \mathrm{W}^{\mathrm{L}}} \mathrm{dInW}^{\mathrm{L}}=\mathrm{dInO} \\
& Z_{\mathrm{Lb} / \mathrm{QL}} \operatorname{dIn} Q^{\mathrm{Ls}}+\mathrm{Z}_{\mathrm{Lb} / \mathrm{W}^{\mathrm{L}}} \mathrm{dInW}^{\mathrm{L}}+\mathrm{Z}_{\mathrm{Lb} / \mathrm{W}^{\mathrm{O}}} \mathrm{dInW}^{\mathrm{O}}+\mathrm{Z}_{\mathrm{Lb} / \mathrm{W}^{\mathrm{Lb}}} \mathrm{dInW}^{\mathrm{L}}+\mathrm{Z}_{\mathrm{Lb} / \mathrm{W}^{\mathrm{f}}} \mathrm{dInW}^{\mathrm{f}}=\mathrm{dInLb} \\
& Z_{f / Q L} d \operatorname{IInQ}^{\mathrm{Ls}}+\mathrm{Z}_{\mathrm{f} / \mathrm{W}^{\mathrm{L}}} \mathrm{dIn} \mathrm{W}^{\mathrm{L}}+\mathrm{Z}_{\mathrm{f} / \mathrm{W}^{\mathrm{O}}} \mathrm{dInW}^{\mathrm{O}}+\mathrm{Z}_{\mathrm{f} / \mathrm{W}^{\mathrm{Lb}}} \mathrm{dInW}^{\mathrm{Lb}}+\mathrm{Z}_{\mathrm{f} / \mathrm{W}^{\mathrm{f}}} \mathrm{dInW}^{\mathrm{f}}=\mathrm{dInf}
\end{aligned}
$$

Using Shephard's lemma, the above output constant equations were derived. The general forms are: $\mathrm{C}_{\mathrm{wL}}=\mathrm{L} ; \mathrm{C}_{\mathrm{wO}}=\mathrm{O}$.

\subsubsection{Supply and Market Clearing Conditions}

$$
\begin{aligned}
& \mathrm{dInL}=\Omega_{\mathrm{L}} \frac{\mathrm{T}}{\mathrm{W}^{\mathrm{L}}} \mathrm{dInW}^{\mathrm{L}}+\Omega_{\mathrm{L}} \frac{\mathrm{T}}{\mathrm{W}^{\mathrm{O}}} \mathrm{dInW}^{\mathrm{O}}+\Omega_{\mathrm{L}} \frac{\mathrm{T}}{\mathrm{W}^{\mathrm{Lb}}} \mathrm{dInW}^{\mathrm{Lb}}+\Omega_{\mathrm{L}} \frac{\mathrm{T}}{\mathrm{W}^{\mathrm{f}}} \mathrm{dInW}^{\mathrm{f}} \\
& \mathrm{dInO}=\Omega_{\mathrm{O}} \frac{\mathrm{T}}{\mathrm{W}^{\mathrm{O}}} \mathrm{dInW}^{\mathrm{O}}+\Omega_{\mathrm{O}} \frac{\mathrm{T}}{\mathrm{W}^{\mathrm{L}}} \mathrm{dInW}^{\mathrm{L}}+\Omega_{\mathrm{O}} \frac{\mathrm{T}}{\mathrm{W}^{\mathrm{Lb}}} \mathrm{dInW}^{\mathrm{Lb}}+\Omega_{\mathrm{O}} \frac{\mathrm{T}}{\mathrm{W}^{\mathrm{f}}} \mathrm{dInW}^{\mathrm{f}} \\
& \mathrm{dInLb}=\Omega_{\mathrm{Lb}} \frac{\mathrm{T}}{\mathrm{W}^{\mathrm{Lb}}} \mathrm{dInW}^{\mathrm{Lb}}+\Omega_{\mathrm{Lb}} \frac{\mathrm{T}}{\mathrm{W}^{\mathrm{O}}} \mathrm{dInW}^{\mathrm{O}}+\Omega_{\mathrm{Lb}} \frac{\mathrm{T}}{\mathrm{W}^{\mathrm{L}}} \mathrm{dInW}^{\mathrm{L}}+\Omega_{\mathrm{Lb}} \frac{\mathrm{T}}{\mathrm{W}^{\mathrm{f}}} \mathrm{dInW}^{\mathrm{f}} \\
& \mathrm{dInf}=\Omega_{\mathrm{f}} \frac{\mathrm{T}}{\mathrm{W}^{\mathrm{f}}} \mathrm{dInW} \mathrm{W}^{\mathrm{f}}+\Omega_{\mathrm{f}} \frac{\mathrm{T}}{\mathrm{W}^{\mathrm{L}}} \mathrm{dInW^{ \textrm {L } }}+\Omega_{\mathrm{f}} \frac{\mathrm{T}}{\mathrm{W}^{\mathrm{Lb}}} \mathrm{dInW} \mathrm{W}^{\mathrm{Lb}}+\Omega_{\mathrm{f}} \frac{\mathrm{T}}{\mathrm{W}^{0}} \mathrm{dInW}^{0}
\end{aligned}
$$

\begin{tabular}{|c|c|c|c|c|c|c|c|c|c|c|c|c|c|}
\hline$d \ln Q_{L}$ & $d \ln Q_{I}$ & $d \ln P_{Q L}$ & $d \ln P_{Q I}$ & $d \ln W_{L}$ & $d \ln W_{L b}$ & $d \ln W_{f}$ & $d \ln W_{o}$ & dln & dlnLb & $d \ln f$ & $d \ln O$ & & \\
\hline-1 & 0 & $\mathrm{HQL} / \mathrm{p}_{\mathrm{QL}}$ & $\mathrm{HQL} / \mathrm{P}_{\mathrm{QI}}$ & 0 & 0 & 0 & 0 & 0 & 0 & 0 & 0 & $d \ln Q_{L}$ & 0 \\
\hline 0 & -1 & HQI/PQL & HQI/PQI & 0 & 0 & 0 & 0 & 0 & 0 & 0 & 0 & $d \ln Q_{I}$ & 0 \\
\hline$(\Sigma \mathrm{Qbs} / \mathrm{PQb})^{-1}$ & 0 & -1 & 0 & $(\Sigma \mathrm{WL} / \mathrm{PQb})^{-1}$ & $\left(\Sigma \mathrm{Wo}_{\mathrm{PQb}}\right)^{-1}$ & $(\Sigma \mathrm{WL} / \mathrm{PQb})^{-1}$ & $(\Sigma \mathrm{Wo} / \mathrm{PQb})^{-1}$ & 0 & 0 & 0 & 0 & dlnPQL & 0 \\
\hline 0 & $(\Sigma \mathrm{Qfs} / \mathrm{PQf})^{-1}$ & 0 & -1 & 0 & 0 & 0 & 0 & 0 & 0 & 0 & 0 & dlnPQI & 0 \\
\hline ZL/QL & 0 & 0 & 0 & $\mathrm{Z}_{\mathrm{L} / \mathrm{WL}}$ & $\mathrm{Z}_{\mathrm{L} / \mathrm{WLb}}$ & $\mathrm{Z}_{\mathrm{L}} / \mathrm{W}_{\mathrm{f}}$ & $\mathrm{Z}_{\mathrm{L} / \mathrm{Wo}_{0}}$ & -1 & 0 & 0 & 0 & $\mathrm{~d} \ln W \mathrm{~L}$ & 0 \\
\hline $\mathrm{ZLb} / \mathrm{QL}$ & 0 & 0 & 0 & $\mathrm{Z}_{\mathrm{Lb} / \mathrm{WL}}$ & $\mathrm{Z}_{\mathrm{O} / \mathrm{WLb}}$ & $\mathrm{ZO} / \mathrm{W}_{\mathrm{f}}$ & $\mathrm{Z}_{\mathrm{Lb} / \mathrm{Wo}_{0}}$ & 0 & -1 & 0 & 0 & $\mathrm{dln} W L b$ & 0 \\
\hline Zf/QL & 0 & 0 & 0 & $\mathrm{Z}_{\mathrm{Wf} / \mathrm{WL}}$ & $\mathrm{Z}_{\mathrm{O} / \mathrm{WLb}}$ & $\mathrm{ZO} / \mathrm{W}_{\mathrm{f}}$ & $Z_{W f / W o}$ & o & 0 & -1 & 0 & dlnWf & 0 \\
\hline $\mathrm{ZO} / \mathrm{QL}$ & 0 & 0 & 0 & $\mathrm{Z}_{\mathrm{O} / \mathrm{WL}}$ & $\mathrm{Z}_{\mathrm{O} / \mathrm{WLb}}$ & $\mathrm{ZO} / \mathrm{W}_{\mathrm{f}}$ & $\mathrm{Z}_{\mathrm{O} / \mathrm{Wo}_{\mathrm{o}}}$ & 0 & 0 & 0 & -1 & dlnWo & 0 \\
\hline 0 & 0 & 0 & 0 & $-\Omega_{\mathrm{L}} / \mathrm{W}_{\mathrm{L}}$ & $-\Omega_{\mathrm{L} / W L b}$ & $-\Omega_{\mathrm{L} / \mathrm{Wf}}$ & $-\Omega_{\mathrm{L} / \mathrm{Wo}_{\mathrm{o}}}$ & -1 & 0 & 0 & 0 & $\mathrm{~d} \ln \mathrm{L}$ & 0 \\
\hline 0 & 0 & 0 & 0 & $-\Omega_{\mathrm{Lb}} / \mathrm{W}_{\mathrm{L}}$ & $-\Omega_{\mathrm{Lb} / \mathrm{WLb}}$ & $-\Omega_{\mathrm{Lb} / \mathrm{Wf}}$ & $-\Omega_{\mathrm{Lb} / \mathrm{Wo}}$ & 0 & -1 & 0 & 0 & $\mathrm{~d} \ln L b$ & 0 \\
\hline 0 & 0 & 0 & 0 & $-\Omega_{\mathrm{f}} / \mathrm{W}_{\mathrm{L}}$ & $-\Omega \mathrm{L} / \mathrm{W}_{\mathrm{Lb}}$ & $-\Omega_{\mathrm{f} / \mathrm{Wf}}$ & $-\Omega f / W_{o}$ & o & 0 & -1 & 0 & $\mathrm{dlnf}$ & 0 \\
\hline 0 & 0 & 0 & 0 & $-\Omega_{\mathrm{O}} / \mathrm{W}_{\mathrm{L}}$ & $-\Omega \mathrm{O} / \mathrm{W}_{\mathrm{Lb}}$ & $-\Omega_{\mathrm{O} / \mathrm{Wf}}$ & $-\Omega_{\mathrm{O} / \mathrm{Wo}}$ & 0 & 0 & 0 & -1 & $\mathrm{~d} \ln \mathrm{O}$ & 0 \\
\hline
\end{tabular}

The above market clearing conditions were used to derive the input supply equations. Here demand is equal to supply.

Using the above equations, a matrix of elasticities and shares was developed. See Table 1 below.

Table 1. Matrix of elasticities and shares

\subsubsection{Welfare Matrix}

In this section, we present the different methods used to populate the welfare matrix above. There are three main methods used to populate welfare matrices in the literature: 1) direct estimation of elasticities, 2) using measures from other authors' estimations and 3) using other professional experiences from other researchers/practitioners. For this research, all three of these methods were employed. Specifically, shares and elasticities in the welfare matrix were obtained partly from the literature of other studies (Cuevas et al., 2016) and from estimation from primary data using willingness-to-pay estimation techniques. Below we discuss the theoretic basis for the 
constraints imposed and a list of the elasticities used (with references) to populate the matrix. For those estimated by the author, full estimation details can be found in the lead author's PhD thesis.

\subsubsection{Demand and Supply Elasticities}

For supply elasticities, by assuming constant returns to scale (CRS), cost is linearly homogenous with respect to output and supply is homogenous of degree 0 with respect to prices. Therefore, inverse supply elasticities horizontally sum to zero. Also, by young's theorem, we assume reciprocity.

Table 2. Demand and supply elasticities

\begin{tabular}{lllll}
\hline$D \ln Q_{L}$ & $D \ln Q_{I}$ & $D \ln P_{L}$ & $D \ln P_{I}$ & \\
\hline-1 & 0 & -1.12 & 0.80 & $D \ln Q L$ \\
0 & -1 & 1.11 & -0.99 & $D \ln Q I$ \\
1.3 & -0.3 & -1 & 0 & $D \ln P L$ \\
-0.3 & 1.3 & 0 & -1 & $D \ln P I$ \\
\hline
\end{tabular}

\subsubsection{Cost Shares}

Assuming CRS, the following input cost shares of land, labour, fertilizer, and other inputs were obtained from the following relationship:

$$
\frac{\mathrm{W}^{1} \mathrm{~L}}{\mathrm{~W}^{1} \mathrm{~L}+\mathrm{W}^{1 \mathrm{~b}} \mathrm{Lb}+\mathrm{W}^{\mathrm{f}} \mathrm{F}+\mathrm{W}^{0} \mathrm{O}}+\frac{\mathrm{W}^{\mathrm{lb}} \mathrm{Lb}}{\mathrm{W}^{1} \mathrm{~L}+\mathrm{W}^{1 \mathrm{~b}} \mathrm{Lb}+\mathrm{W}^{\mathrm{f}} \mathrm{F}+\mathrm{W}^{0} \mathrm{O}}+\frac{\mathrm{W}^{\mathrm{f}} \mathrm{F}}{\mathrm{W}^{\mathrm{l}} \mathrm{L}+\mathrm{W}^{1 \mathrm{~b}} \mathrm{Lb}+\mathrm{W}^{\mathrm{f}} \mathrm{F}+\mathrm{W}^{0} \mathrm{O}}+\frac{\mathrm{W}^{\mathrm{o}} \mathrm{O}}{\mathrm{W}^{\mathrm{l}} \mathrm{L}+\mathrm{W}^{\mathrm{lb}} \mathrm{Lb}+\mathrm{W}^{\mathrm{f}} \mathrm{F}+\mathrm{W}^{\mathrm{o} O}}=1
$$

Where, $\mathrm{W}^{\mathrm{L}}=$ Land prices $; \quad \mathrm{W}^{\mathrm{Lb}}=$ Prices of labour $; \quad \mathrm{W}^{\mathrm{f}}=$ Prices of fertilizer $; \mathrm{W}^{\mathrm{O}}=$ Prices of other inputs ; $\mathrm{L}=$ Total Land used by local rice producers; $\mathrm{O}=$ other inputs used by the local rice producing industry; $\mathrm{Lb}=$ Labour; $\mathrm{F}=$ Fertilizer.

The share of producer costs that went towards expenses on these inputs were obtained from the survey. Note that majority of the other inputs included mainly seeds. Also, the analysis assumed that there are no costs incurred domestically for the production of imported rice, hence, the cost shares were negligible.

Table 3. Input shares

\begin{tabular}{lllll}
\hline$d \ln W_{L}$ & $d \ln W_{L b}$ & $d \ln W_{f}$ & $d \ln W_{o}$ & \\
\hline 0.12 & 0.42 & 0.23 & 0.23 & $d \ln P_{Q L}$ \\
0 & 0 & 0 & 0 & $d \ln P Q_{I}$ \\
\hline
\end{tabular}

\subsubsection{Input Demand Elasticities and Shares}

Input derived demands are homogenous of degree zero in input prices. Therefore; the derived demand elasticities should sum to zero and reciprocity is imposed. The diagonal is negative because the cost function is assumed concave.

By constant returns to scale and given the fact that there are inputs factored in the system for imported rice, the input demand elasticities are represented to be 1 for all inputs.

Table 4. Input demand elasticities and shares

\begin{tabular}{lllllll}
\hline & $\mathrm{d} \ln Q \mathrm{~L}$ & $\mathrm{~d} \ln \mathrm{QI}$ & $\mathrm{d} \ln \mathrm{WL}$ & $\mathrm{d} \ln \mathrm{WLb}$ & $\mathrm{d} \ln \mathrm{Wf}$ & $\mathrm{d} \ln$ Wo \\
\hline $\mathrm{d} \ln \mathrm{WL}$ & 1 & 0 & -0.9 & 0.4 & 0.2 & 0.3 \\
$\mathrm{~d} \ln \mathrm{WLb}$ & 1 & 0 & 0.4 & -0.7 & 0.1 & 0.2 \\
$\mathrm{~d} \ln W f$ & 1 & 0 & 0.2 & 0.1 & -0.64 & 0.26 \\
dlnWo & 1 & 0 & 0.3 & 0.28 & 0.26 & -0.84 \\
\hline
\end{tabular}

\subsubsection{Elasticities of Inputs Supply}

Here, it is assumed that there are no cross-price elasticity effects with inputs. That is, the price of land has negligible effects on farmers demand for fertilizer. Hence, only own price elasticities of inputs are considered. 
For the same reasons discussed above under output own supply elasticities, input own elasticities are assumed to be positive.

Table 5. Elasticities of inputs supply

\begin{tabular}{lllll}
\hline $\mathrm{d} \ln W L$ & $\mathrm{~d} \ln W L b$ & $\mathrm{~d} \ln W f$ & $\mathrm{~d} \ln \mathrm{W}$ & \\
\hline 1.5 & 0 & 0 & 0 & $\mathrm{~d} \ln W \mathrm{~L}$ \\
0 & 1.9 & 0 & 0 & $\mathrm{~d} \ln W \mathrm{Lb}$ \\
0 & 0 & 0.8 & 0 & $\mathrm{~d} \ln W f$ \\
0 & 0 & 0 & 1.29 & $\mathrm{~d} \ln W o$ \\
\hline
\end{tabular}

See appendix 1 for the complete welfare matrix. From Table 1 above, Assuming A to be the welfare matrix of endogenous variables, solving the equation $A_{12 \times 12} \cdot X_{12 \times 1}=b_{12 \times 1}$ helps us characterize the market effects of the shocks introduced. The resulting estimates of $\mathrm{X}$ (market effects) represent the percentage by which the different market parameters change for the percentage increase in the shock. Furthermore, given the linear relationship between $\mathrm{X}$ and $\mathrm{b}$, the magnitude of the shock has no effect on the direction of the market effects.

\subsubsection{Welfare Estimation: Consumer and Producer Surplus}

The measurement of welfare has seen decades of evolution particularly as practitioners' attempt to narrow the gap between theory and practice. For simplicity and data limitations, classic welfare measurement techniques were adopted for this research; "changes in Consumer and Produce Surplus". The welfare effects of an equilibrium change are generally approximated as the changes in consumer and produce surplus.

Figure 2 below shows an illustration of Consumer Surplus and Producer Surplus. Consumer Surplus represents the difference between the total amount consumers are willing and able to pay for a good or service and the total amount they pay. On the other hand, producer surplus represents the difference between the total amount producers are willing and able to sell their produce and what they sell it for.

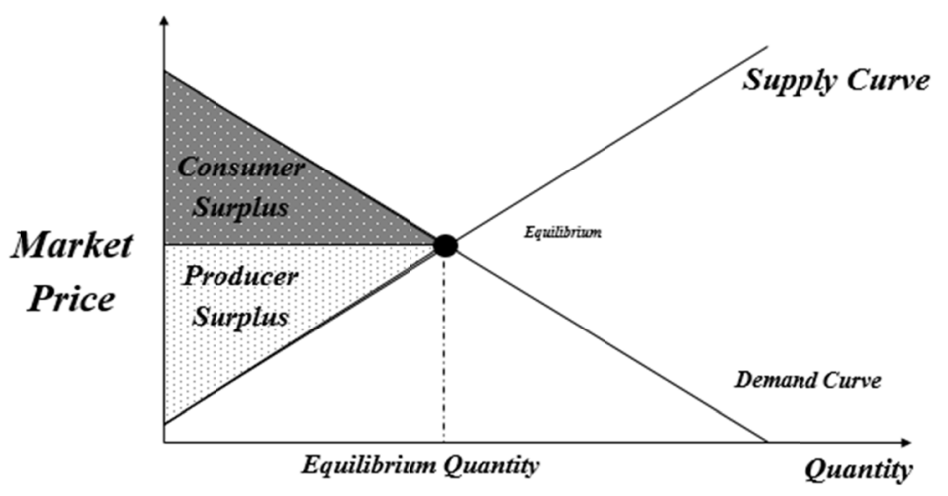

Figure 2. Welfare measures

The welfare effects of an equilibrium change are generally approximated as the changes in consumer and producer surplus. In a multimarket framework using log-linear comparative static techniques welfare changes as a result of exogenous shocks can be expressed as fractions of the initial value of the good. If demand and supply curves are stationary, the relationship used to compute these welfare measures are as shown below:

$$
\begin{gathered}
\Delta \text { Consumer Welfare } / \mathrm{P}_{\mathrm{i} 0} \mathrm{Q}_{\mathrm{i} 0}=\left(-\mathrm{d} \ln \mathrm{p}_{\mathrm{id}}\left(1+\ln \mathrm{Q}_{\mathrm{i} / 2}\right)\right. \\
\Delta \text { Producer Welfare } / \mathrm{P}_{\mathrm{i} 0} \mathrm{Q}_{\mathrm{i} 0}=\left(\mathrm{d}_{\ln } \mathrm{p}_{\mathrm{is}}\left(1+\ln \mathrm{Q}_{\mathrm{i} / 2}\right)\right.
\end{gathered}
$$

Where, $\mathrm{P}_{\mathrm{i} 0}=$ initial price before the shock was introduced for market $\mathrm{i} ; \mathrm{Q}_{\mathrm{i} 0}=$ initial quantity before the shock was introduced for market $\mathrm{i}$.

This computation of change in consumer surplus is obtained by summing the rectangle measured by the change in equilibrium product price multiplied by the initial quantity (area of rectangle) and the triangle measured by half of the change in price multiplied by the change in equilibrium quantity (area of triangle). Changes in 
producers' surplus in each of the input markets are measured by a comparable trapezoid under the new price for that input.

\section{Results}

In this section, we provide summaries of the key results obtained from this study. The results are presented in two main parts. The first section presents results from the market effects while the second part presents results from the welfare effects.

\subsection{Market Effects}

Following the estimation of elasticities and appropriate completion of the welfare matrix, the market effects of the different policy scenarios are presented. Simulations were carried out for different levels of the shocks to determine the degrees and directions of change for multiple levels. Therefore, these market effects show mainly the magnitude and directional changes in process (input and output) and quantities for the two products (imported rice and locally produced rice). Results are presented for the respective policy scenarios.

\subsubsection{Market Effects of Reinstating Tariffs on Imported Rice on Smallholder Rice Farmers in Sierra Leone}

The government of Sierra Leone in 2010 made a strategic food security policy decision to lift a $10 \%$ tariff on all imported rice into Sierra Leone. In this section, the market effects as a result of reinstating this tariff are presented. In addition, some simulations were carried out to see the effects under four addition tariff rate scenarios $(5 \%, 10 \%, 20 \%$ and $30 \%)$. Results are presented in Table 6 below:

Table 6. Markets effects of reinstating tariff on rice importation into Sierra Leone

\begin{tabular}{l|llllllllllll}
\hline \multicolumn{1}{l}{ Shocks } & $\mathrm{d} \ln \mathrm{Q}_{\mathrm{L}}$ & $\mathrm{d} \ln \mathrm{Q}_{\mathrm{I}}$ & $\mathrm{d} \ln \mathrm{P}_{\mathrm{QL}}$ & $\mathrm{d} \ln \mathrm{P}_{\mathrm{QI}}$ & $\mathrm{d} \ln \mathrm{W}_{\mathrm{L}}$ & $\mathrm{d} \ln \mathrm{W}_{\mathrm{Lb}}$ & $\mathrm{d} \ln \mathrm{W}_{\mathrm{f}}$ & $\mathrm{d} \ln _{\mathrm{o}}$ & $\mathrm{dln}_{\mathrm{L}}$ & $\mathrm{dln}_{\mathrm{Lb}}$ & $\mathrm{Dln}_{\mathrm{f}}$ & $\mathrm{dln}_{\mathrm{O}}$ \\
\hline $5 \%$ & $3.01 \%$ & $-0.92 \%$ & $-1.29 \%$ & $5.56 \%$ & $2.08 \%$ & $1.77 \%$ & $2.91 \%$ & $2.29 \%$ & $3.12 \%$ & $3.35 \%$ & $2.33 \%$ & $2.96 \%$ \\
$10 \%$ & $6.02 \%$ & $-1.84 \%$ & $-2.57 \%$ & $11.13 \%$ & $4.15 \%$ & $3.53 \%$ & $5.83 \%$ & $4.59 \%$ & $6.23 \%$ & $6.71 \%$ & $4.66 \%$ & $5.92 \%$ \\
$20 \%$ & $12.04 \%$ & $-3.69 \%$ & $-5.15 \%$ & $22.25 \%$ & $8.31 \%$ & $7.06 \%$ & $11.66 \%$ & $9.17 \%$ & $12.46 \%$ & $13.42 \%$ & $9.33 \%$ & $11.83 \%$ \\
$30 \%$ & $18.05 \%$ & $-5.53 \%$ & $-7.72 \%$ & $33.38 \%$ & $12.46 \%$ & $10.59 \%$ & $17.49 \%$ & $13.76 \%$ & $18.70 \%$ & $20.12 \%$ & $13.99 \%$ & $17.75 \%$ \\
\hline
\end{tabular}

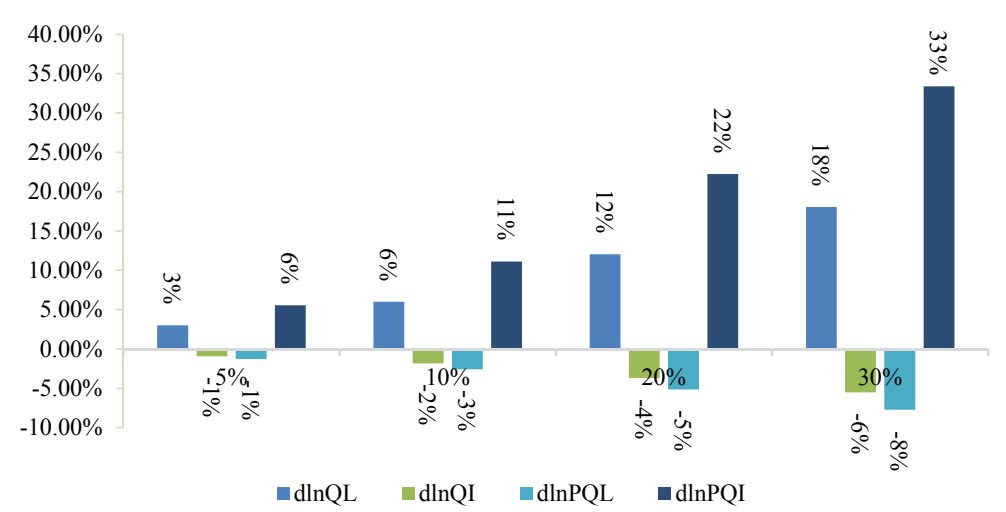

Figure 1. Market effects on equilibrium quantities of demand and supply of imported and locally produced rice

Figure 3 above shows market effects of the four tariff scenarios on equilibrium prices and quantities demanded and supplied of both locally produced rice and imported rice. As shown, equilibrium quantities demanded and supplied increased for locally produced rice while that for imported rice decreased for all four scenarios. For a $5 \%$ tariff, equilibrium quantities of locally produced rice increased by $3 \%$ while the decrease in equilibrium quantities for imported rice was about $0.92 \%$. These rates steadily increased in magnitude (in the same directions) as tariff rates increased from $5 \%$ to $30 \%$. For prices, locally produced rice prices decreased while significant increases were recorded for imported rice prices. 


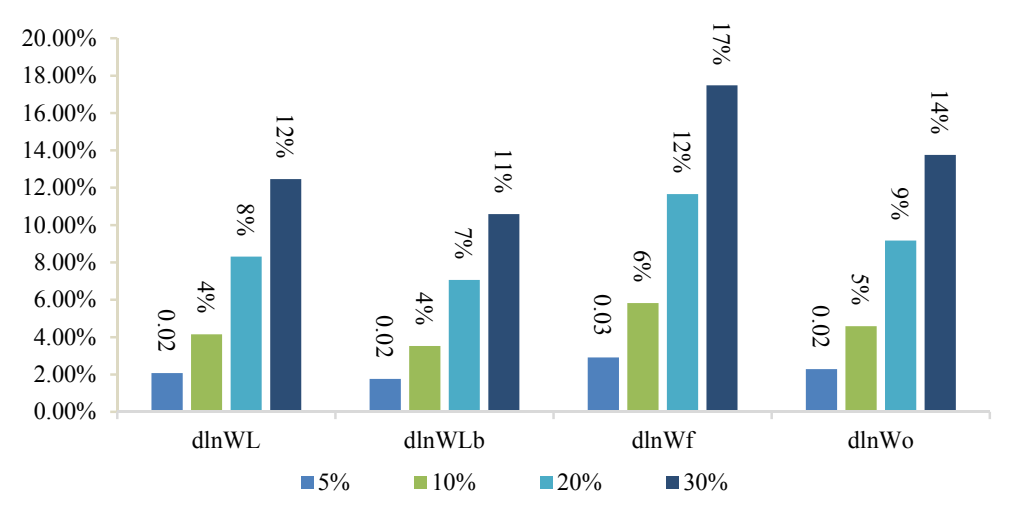

Figure 2. Market effects on input prices (land, labour, fertilizer and others)

Figure 4 above shows market effects of inputs as a result of reinstating tariffs. As shown, all input prices increased as a result of the shocks with labour prices (wages) recording the lowest increases while cost of fertilizer recording the highest. Similar trends were also recorded for quantities demanded and supplied of these inputs. However, demand was highest for labour and lowest for fertilizer (See Figure 5 below).

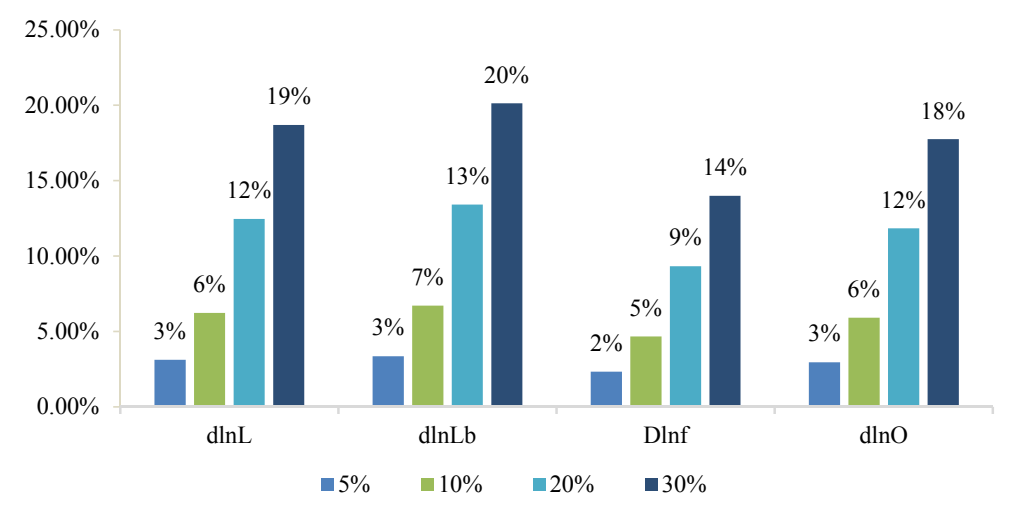

Figure 3. Market effects on equilibrium quantities supplied and demanded of inputs

\subsubsection{Market Effects of an Increase in Supply of Local Rice Production}

Table 7. Market effects of an increase in the supply of local rice production

\begin{tabular}{|c|c|c|c|c|c|c|c|c|c|c|c|c|}
\hline & $\mathrm{d} \ln \mathrm{QL}$ & dlnQI & dlnPQL & dlnPQI & $\operatorname{lnWL}$ & dlnWLb & dlnWf & $\ln$ Wo & $d \ln L$ & $\operatorname{lnLb}$ & Dlnf & $\mathrm{d} \ln \mathrm{O}$ \\
\hline $10 \%$ & $0.85 \%$ & $-7.79 \%$ & $-12.79 \%$ & $6.47 \%$ & $0.59 \%$ & $0.50 \%$ & $0.83 \%$ & $0.65 \%$ & $0.88 \%$ & $0.95 \%$ & $0.66 \%$ & $0.84 \%$ \\
\hline $20 \%$ & $1.70 \%$ & $-15.58 \%$ & $-25.58 \%$ & $12.94 \%$ & $1.18 \%$ & $1.00 \%$ & $1.65 \%$ & $1.30 \%$ & $1.76 \%$ & $1.90 \%$ & $1.32 \%$ & $1.67 \%$ \\
\hline $30 \%$ & $2.56 \%$ & $-23.37 \%$ & $-38.37 \%$ & $19.4 \%$ & $1.76 \%$ & $1.50 \%$ & $2.48 \%$ & $1.95 \%$ & $2.65 \%$ & $2.85 \%$ & $1.98 \%$ & $2.51 \%$ \\
\hline $40 \%$ & $3.41 \%$ & $-31.16 \%$ & $-51.16 \%$ & $25.88 \%$ & $2.35 \%$ & $2.00 \%$ & $3.30 \%$ & $2.60 \%$ & $3.53 \%$ & $3.80 \%$ & $2.64 \%$ & $3.35 \%$ \\
\hline
\end{tabular}

In this section we present the market effects as a result of increasing supply of locally produced rice. The shock to the system was applied to the local rice market demand and supply equation. As shown in Table 7 above, quantities of imported rice demanded and supplied decreased increasingly for the four different shocks applied. On the same note, equilibrium prices of locally produced rice decreased. On the other hand, all other market effects increased with the increases in input prices and demand being very marginal.

The effect of a quota was also explored. In the context of the full system, the shock that would emanate from a quota to the systems would be a decrease in quantity supplied and demanded of imported rice. This would have identical effects as those presented in reinstating the tariff. 


\subsection{Welfare Effects}

In this section, we present results of welfare effects from the three-policy scenarios analysed. These are computed from changes recorded in the market effect analysis above. Similarly, results are presented for the different policy scenarios.

3.2.1 Welfare Effects of Reinstating Tariffs on Rice Imports

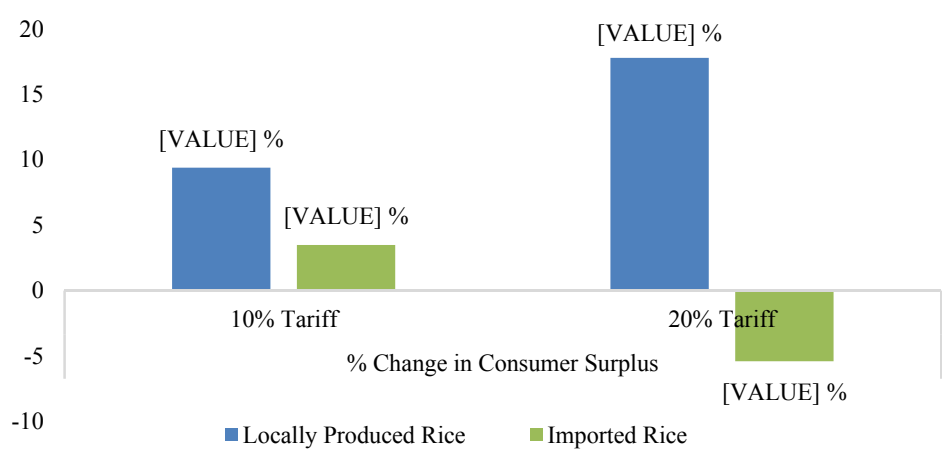

Figure 7. Consumer surplus

Figure 6 above present's changes in consumer surplus on consumers of locally produced rice and imported rice in response to $10 \%$ and $20 \%$ tariffs on imported rice. As shown, welfares of consumers of locally produced rice is enhanced by $9.4 \%$ as a result of a $10 \%$ tariff increase and $17.8 \%$ as a result of a $20 \%$ tariff increase. For consumers of imported rice, welfare is enhanced by $3.5 \%$ for a $10 \%$ tariff increase but dis-enhanced by $5.4 \%$ as a result of a $20 \%$ tariff increase.

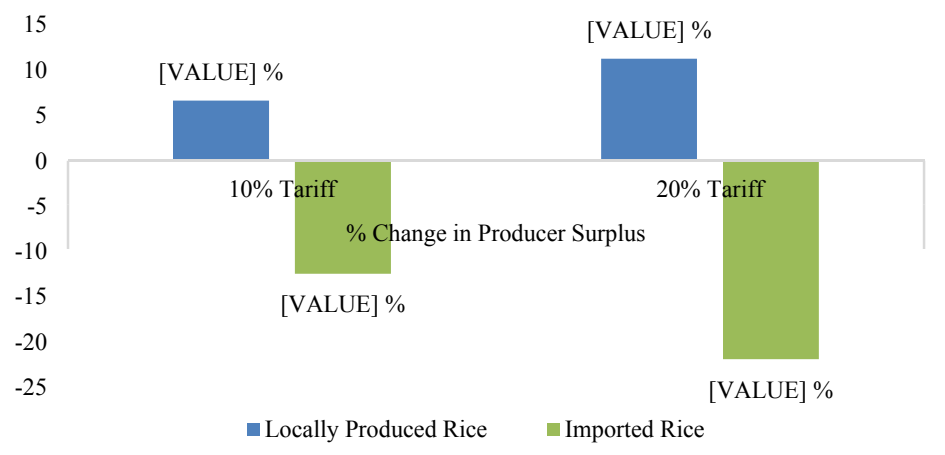

Figure 7. Producer surplus

For producers, welfare of local rice producers was enhanced while those of imported rice suppliers (importers) were dis-enhanced. For the local rice producers, a $10 \%$ tariff enhanced welfare by $6.65 \%$ while a $20 \%$ tariff enhanced welfare by $11.27 \%$.

\subsubsection{Welfare Effects of Increasing Supply of Locally Produced Rice}

In this section, we present welfare results as a result of increasing supply of locally produced rice. Shocks of $10 \%$ and $20 \%$ were introduced to the equilibrium system representing local rice supply increases.

As shown in Figure 8 below, welfare of consumers of both produces were enhanced. However, the enhancements were higher for consumers of locally produced rice than consumers of imported rice. For consumers of locally produced rice, $10 \%$ supply increases in local rice production enhanced welfare by $14.43 \%$ while enhancement was at $27.0 \%$ for a $20.0 \%$ increase in supply. For consumers of imported rice, a $10.0 \%$ increase in supply of locally produced rice enhanced welfare by $2.2 \%$ and by $7.5 \%$ for $20.0 \%$ increases in supply of locally produced rice. 


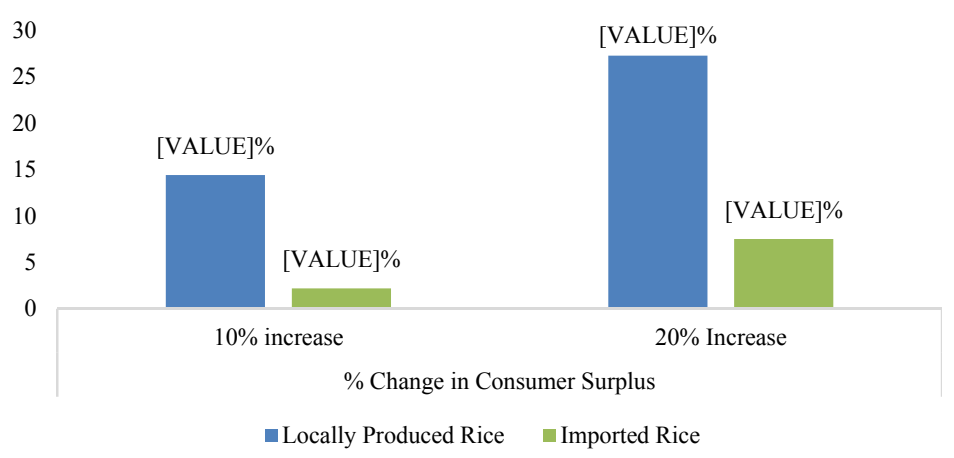

Figure 4. Consumer surplus

Similarly, for producers, welfare gains were recorded for producers of locally produced rice and for rice importers, although the gains were larger for local rice producers.

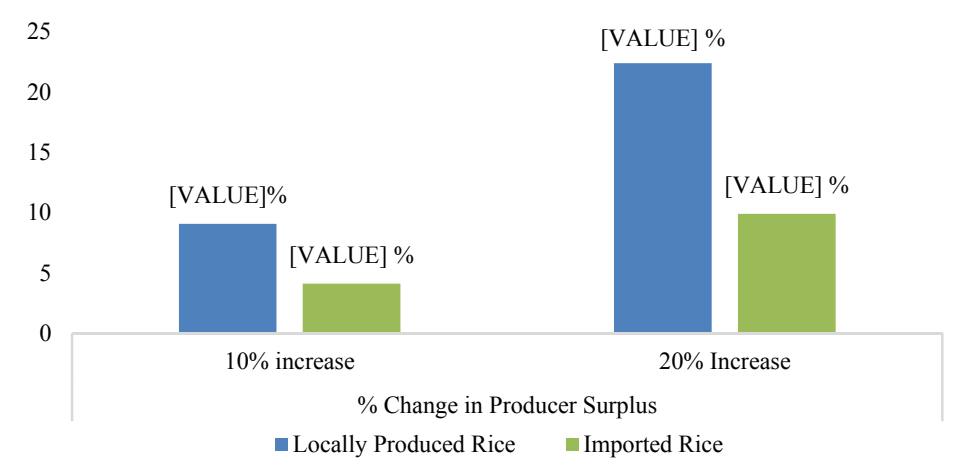

Figure 5. Producer surplus

\subsubsection{Welfare Effects of Instituting an Import Quota on Rice}

In the system highlighted above, the shock that would be introduced is identical to that of scenario one's; decreased supply as a result of the tariff. However, to better understand the ramifications of the quota, a more detailed analysis is present in the upstream analysis that excludes the effects or contributions of inputs in the system of equations developed.

\subsection{Summary of Results}

Tables 8,9 and 10 below summarize all the results obtained from the analysis, showing winners and losers as a result of the different policies. 
Table 8. Market effects of policy 1 and 2

\begin{tabular}{llll}
\hline Shocks & Policy 1 & Policy 2 & Winners and Losers \\
\hline$d \ln Q_{L}$ & $6.02 \%$ & $0.85 \%$ & Smallholder rice consumers and producers of locally produced rice are welfare enhanced. \\
\hline$d \ln Q_{I}$ & $-1.84 \%$ & $-7.79 \%$ & Rice importers loose as a result of the additional costs associated with the tariff. \\
\hline$d \ln P_{Q L}$ & $-2.57 \%$ & $-12.79 \%$ & Consumers of locally produced rice gain as a result of the associated price decrease. \\
\hline$d \ln P_{Q I}$ & $11.13 \%$ & $6.47 \%$ & Consumers of imported rice suffer a large price increase. \\
\hline$d \ln W L$ & $4.15 \%$ & $0.59 \%$ & \\
$d \ln W L b$ & $3.53 \%$ & $0.50 \%$ & \\
$d \ln W f$ & $5.83 \%$ & $0.83 \%$ & Generally, associated with these gains accrued from consumption of locally produced rice, \\
$d \ln W o$ & $4.59 \%$ & $0.65 \%$ & input prices increase, and demand and supply of these inputs also increase. This is expected as \\
$d \ln L$ & $6.23 \%$ & $0.88 \%$ & the increased demand would pull production levels, hence, increasing demand and cost of inputs. \\
$d \ln L b$ & $6.71 \%$ & $0.95 \%$ & \\
$D \ln f$ & $4.66 \%$ & $0.66 \%$ & \\
$d \ln O$ & $5.92 \%$ & $0.84 \%$ & \\
\hline
\end{tabular}

Table 9. Welfare effects of reinstating tariff on rice importation

\begin{tabular}{|c|c|c|}
\hline \multirow{2}{*}{ Welfare Measure } & \multicolumn{2}{|r|}{ Reinstating the Rice Tariff } \\
\hline & \% Changes & Winners and Losers \\
\hline \multirow{3}{*}{ Change in Consumer Surplus Imported Rice } & & Consumers of imported rice enjoy enhanced welfare marginally. \\
\hline & $3.5 \%$ & However, it is important to note that at $20 \%$ the welfare gains are dis-enhancing. \\
\hline & & This suggest that ardent consumers of imported rice would lose eventually. \\
\hline Change in Producer Surplus Imported Rice & -12.45 & Supplier of imported rice lose significantly as a result of reinstating the tariff. \\
\hline Change in Consumer Surplus Locally Produced Rice & $9.4 \%$ & Consumers of locally produced rice (average sierra Leonean) benefit. \\
\hline Change in Producer Surplus Locally Produced Rice & $6.67 \%$ & $\begin{array}{l}\text { Producers of local rice (all smallholder rice farmers) gain as a result of } \\
\text { reinstating the tariff. }\end{array}$ \\
\hline
\end{tabular}

Table 10. Welfare effects of increasing production of local rice

\begin{tabular}{lll}
\hline \multirow{2}{*}{ Welfare Measure } & \multicolumn{1}{c}{ Increased Production of Locally Produced Rice } \\
\cline { 2 - 3 } & $\mathbf{\%}$ Changes & Winners and Losers \\
\hline Change in Consumer Surplus Imported Rice & $2.2 \%$ & This leads to a win-win solution for all consumers and smallholder rice \\
Change in Producer Surplus Imported Rice & $4.12 \%$ & $\begin{array}{l}\text { producers/suppliers. However, the increases/welfare enhancements are } \\
\text { greater for locally produced rice than is the case for imported rice. }\end{array}$ \\
Change in Consumer Surplus Locally Produced Rice & $14.43 \%$ & \\
Change in Producer Surplus Locally Produced Rice & $9.08 \%$ & \\
\hline
\end{tabular}

\section{Concluding Remarks}

Rice importation in Sierra Leone continues to be a major bottleneck affecting smallholder rice farmers in the country. In addition to its direct effect rice production, it also affects the country's foreign reserves and other macroeconomic indicators of economic growth. As policy makers grapple with this problem, different options have been considered as possible solutions to this problem. However, the lack of empirical evidence showing the potential ramifications of these policy options has made it difficult for policy makers to provide meaningful solutions to the problem. For the most part, the options that have been tried are very ad-hoc in nature. This research is a step in that direction, attempting to provide some answers to these questions. Primarily, the study shows the market and welfare effects of three policy options currently being considered: 1) reinstating tariffs on rice imports, 2) increasing local rice supply (production) through direct government interventions and 3) instituting a quota on imports. In this section the key conclusions obtained from the analysis are presented. Some policy recommendations that would help improve the rice market and enhance welfare of smallholder rice farmers and consumers in the country are also highlighted.

Results showed that reinstating tariffs on imported rice increases equilibrium quantities demanded and supplied of locally produced rice. This gain was observed to be significantly higher with reinstating the tariff than the shock associated with increased supply of locally produced rice. This implies that increasing local supply of locally produced rice has a lesser impact on equilibrium quantities of locally produced rice than reinstating tariffs on imported rice. 
Results also show that the effects on prices significantly favour consumers of locally produced rice. There are certainly negative ramifications on local rice producers as a result of the price decrease. However, the results on equilibrium quantities suggest that farmers are still willing and able to supply more under the different policy scenarios. Generally, associated with these gains accrued from consumption of locally produced rice, input prices increase, and demand and supply of these inputs also increase.

Regarding welfare, significant welfare gains were recorded on the local rice market (consumers and producers) when the tariff was reinstated. However, consumers and importers of imported rice did not register welfare gains. On the other hand, the effect of increased production leads to win-win solution for all consumers and smallholder rice producers/suppliers. However, the increases/welfare enhancements are greater for locally produced rice than is the case for imported rice.

The case of quotas should also be considered. This is because it leads to a win-win solution for both rice importation market and the local rice producing market.

Concluding, there are indeed negative and positive ramifications of these three welfare policies investigated. As a result of this, multiple policies should be considered to address the rice situation in Sierra Leone. Reinstating the tariffs in a staggered manner and investing in initiatives that increase local rice production is strongly recommended.

For the tariff reinstatement, a more feasible option is having the tariff reinstated over a period of 5 years. This should be done such that minute proportions are levied annually (5\% annually). Every year the effects are reviewed, and incremental percentages instituted.

However, giving the current landscape coupled with the low level of rice production and productivity over the last two year's production cycle (as a result of the Ebola Virus Disease) it is recommended that local policies that increase local supply be enacted in the next three years to allow the sector to recover completely. Tariff reinstatement should be strongly considered in the third year as recommended above.

\section{References}

Conteh, A., Yan, X., \& Sankoh, F. (2012). The influence of price on rice production in Sierra Leone. Agricultural Sciences, 3, 462-469. https://doi.org/10.4236/as.2012.34054

Cuevas, R. P., Pede, V. O., McKinley, J., Velarde, O., \& Demont, M. (2016). Rice Grain Quality and Consumer Preferences: A Case Study of Two Rural Towns in the Philippines. PLoS ONE, 11(3), e0150345. https://doi.org/10.1371/journal.pone.0150345

FAO/WFP. (2015). FAO/WFP Crop and Food Security Assessment-Liberia, Sierra Leone and Guinea. Retrieved from http://www.fao.org/3/a-i4311e.pdf

FAOSTAT. (2013, 2014, 2015). Selected Indicators-Sierra Leone and Liberia [Dataset]. Retrieved from http://www. fao.org/faostat/en/\#home

FEWSNET/FAO/WFP/MAFFS. (2010). Cross-border trade and food security in Liberia and Sierra Leone.

Gohin, A., \& Bureau, J.-C. (2006). Modelling the EU sugar supply to assess sectoral policy reforms. European Review of Agricultural Economics, 33(2), 223-47. https://doi.org/10.1093/erae/jbl006

Hertel, T. W. (1992). Partial versus General Equilibrium Analysis of Trade Policy Reform. The Journal of Agricultural Economics Research, 44(3), 3-15.

Hertel, T. W. (2002). Chapter 26: Applied General Equilibrium Analysis of Agricultural and Resource Policies. Handbook of Agricultural Economics, 2(Part A), 1373-1419. https://doi.org/10.1016/S1574-0072(02) 10008-9

Muth, R. F. (1964). The Derived Demand Curve for a Productive Factor and the Industry Supply Curve. Oxford Economic Papers, 16(2), 221-234. https://doi.org/10.1093/oxfordjournals.oep.a040951

PEMSD. (2012). Planning Evaluation, Monitoring and Statistics Department Annual Consumption Data.

Perin, R. K. (1997). The Impact of Technological Change on a competitive Industry. Journal of Agricultural and Resource Economics.

Salhofer, K., \& Sinabell, F. (1999). Utilising Equilibrium-Displacement Models to Evaluate the Market Effects of Countryside Stewardship Policies: Method and Application. 
SIPAG. (2010). Cross-border trade and food security in Liberia and Sierra Leone.

Spencer, D. S. C. (1997). Rice Trade and Price Policy Study. The Government of Sierra Leone, Ministry of Agriculture and Natural Resources and the World Bank (Agriculture Sector Support Project); Dunstan Spencer and Associates, Sierra Agricultural Services, and Ajua Consultants Ltd., Freetown, Sierra Leone. Retrieved from http://www.eds-sl.com/docs/SierraLeone-RicePolicyStudyFinal-Jan1997.pdf

Spencer, D. S. C., Deen, S., \& Wilson, C. (2009). Economics of Rice Production in Sierra Leone. Freetown, Sierra Leone.

Sumner, D. A., \& Wohlgenant, M. K. (1985). Effects of an increase in the federal excise tax on cigarettes. Am. J. Agric. Econ., 67, 235-42. https://doi.org/10.2307/1240674

Wiggins, S., Compton, J., Keats, S., \& Davies, M. (2010). Country Responses to the Food Price Crisis 2007/08. London: UKAID.

World Bank. (2014). Rice Prices in Sierra Leone. Retrieved from https://www.statistics.sl/images/StatisticsSL/ Documents/rice_prices_in_sierra_leone.pdf

World Data Atlas. (2018). Sierra Leone-Rice imports [Dataset]. Retrieved from https://knoema.com/atlas/ Sierra-Leone/topics/Agriculture/Trade-Import-Value/Rice-imports

\section{Appendix A}

\section{Matrix of Elasticities and Shares}

\begin{tabular}{|c|c|c|c|c|c|c|c|c|c|c|c|c|c|c|}
\hline$d \ln Q_{L}$ & $\mathrm{~d} \ln \mathrm{Q}_{\mathrm{I}}$ & $\mathrm{d} \ln \mathrm{P}_{\mathrm{QL}}$ & $\mathrm{d} \ln \mathrm{P}_{\mathrm{QI}}$ & $d \ln W_{L}$ & $\mathrm{~d} \ln \mathrm{W}_{\mathrm{Lb}}$ & $d \ln W_{f}$ & $\mathrm{~d} \ln \mathrm{W}_{\mathrm{o}}$ & $\mathrm{d} \ln \mathrm{L}$ & $\mathrm{d} \ln L b$ & $D \operatorname{lnf}$ & $\mathrm{d} \ln \mathrm{O}$ & & & \\
\hline-1 & 0 & 1.12 & 0.8 & 0 & 0 & 0 & 0 & 0 & 0 & 0 & 0 & $d \ln Q_{L}$ & & 0 \\
\hline 0 & -1 & 1.11 & 0.99 & 0 & 0 & 0 & 0 & 0 & 0 & 0 & 0 & $\mathrm{~d} \ln \mathrm{Q}_{\mathrm{I}}$ & & 0 \\
\hline-0.65 & 1.65 & -1 & 0 & 0.12 & 0.42 & 0.23 & 0.23 & 0 & 0 & 0 & 0 & $\mathrm{~d} \ln \mathrm{P}_{\mathrm{QL}}$ & & 0 \\
\hline 1.65 & -0.65 & 0 & -1 & 0 & 0 & 0 & 0 & 0 & 0 & 0 & 0 & $\mathrm{~d} \ln \mathrm{P}_{\mathrm{QI}}$ & & 0 \\
\hline 1 & 0 & 0 & 0 & -0.9 & 0.4 & 0.2 & 0.3 & -1 & 0 & 0 & 0 & dlnWL & & 0 \\
\hline 1 & 0 & 0 & 0 & 0.4 & -0.7 & 0.1 & 0.2 & 0 & -1 & 0 & 0 & $\mathrm{~d} \ln W L b$ & - & 0 \\
\hline 1 & 0 & 0 & 0 & 0.2 & 0.1 & -0.64 & 0.26 & 0 & 0 & -1 & 0 & $\mathrm{~d} \ln W f$ & & 0 \\
\hline 1 & 0 & 0 & 0 & 0.3 & 0.28 & 0.26 & -0.84 & 0 & 0 & 0 & -1 & dlnWo & & 0 \\
\hline 0 & 0 & 0 & 0 & 1.5 & 0 & 0 & 0 & -1 & 0 & 0 & 0 & $\mathrm{~d} \ln \mathrm{L}$ & & 0 \\
\hline 0 & 0 & 0 & 0 & 0 & 1.9 & 0 & 0 & 0 & -1 & 0 & 0 & $\mathrm{~d} \ln \mathrm{Lb}$ & & 0 \\
\hline 0 & 0 & 0 & 0 & 0 & 0 & 0.8 & 0 & 0 & 0 & -1 & 0 & Dlnf & & 0 \\
\hline 0 & 0 & 0 & 0 & 0 & 0 & 0 & 1.29 & 0 & 0 & 0 & -1 & $\mathrm{~d} \ln \mathrm{O}$ & & 0 \\
\hline
\end{tabular}

Source: Author's survey data.

\section{Copyrights}

Copyright for this article is retained by the author(s), with first publication rights granted to the journal.

This is an open-access article distributed under the terms and conditions of the Creative Commons Attribution license (http://creativecommons.org/licenses/by/4.0/). 